\title{
THE IMPACT OF INFORMATION ASYMMETRY, MORAL HAZARD AND THE STRUCTURE OF FUNDING ON CORPORATE U.S. DOLLARS LOAN PRICING: THE EMPIRICAL STUDY IN INDONESIA THE PERIOD 1990-1997
}

\author{
Deddy Marciano \\ Faculty of Business and Economics \\ Surabaya University \\ Suad Husnan \\ Faculty of Business and Economics \\ Gadjah Mada University
}

\begin{abstract}
This study aims to answer the question: "What factors that influence the price of corporate loans in Indonesia?" And "Are there some differences in loan pricing between several types of creditors?". Furthermore, this research is to develop and test the loan pricing model that was developed in America and Europe to the context or setting in Asia, especially Indonesia. Different conditions and settings of the financial system between America/Europe and Asia, especially Indonesia, causing the loan pricing model that was developed in America/Europe can not be fully implemented for Indonesia.

Key issues in this study consisted of: information asymmetry, moral hazard and funding structure. The first issue, information asymmetry consists of the type of creditors, foreign and domestic ownership, public and non-public ownership. The second issue, moral hazard problem consists of variables governmental and non-government ownership, and the special relationship between creditors and debtors. The last issue, creditors' structure of funding is proxied by the ratio of CD / ML. In addition, this study also adobt the loan pricing models that are developed in America / Europe as control variables. This study also examines the argument of Strahan (1999) whether the loan fees also reflected the condition of the loan as well as loan spreads.

The OLS regression (Ordinary Least Squares) with white correction method (White heteroskedasticity correction) for heteroscedasticity problem is conducted to test the model. Various samples and sub samples are prepared to answer various research questions and hypotheses. Testing between regression coefficients are conducted to examine differences in loan pricing between different types of creditors for each variable in the model.

The test results generally show that only two new variables suggested by the study, namely: ownership and structure of funding have a significant contribution to the loan pricing model. For variable type of institution consisting of investment banks and commercial banks indicate that generally there is no difference in loan pricing between the two, only in some models of these variables are not significant with signs consistent.Ownership variable show results consistent with the hypothesis and significant effect on loan prices. While the variable special relationship between creditors and debtors have no effect on loan prices, it is due to inter-group loans made by conglomerates. For the case of capital costs of the creditor shows that the variable has a positive effect on lending rates set by creditors. Testing different regression coefficients lead to the conclusion that domestic creditors succeeded in detecting an increased risk of the debtor before the economic crisis of 1997 compared with foreign creditors.
\end{abstract}

Keywords:

Asymmetric information, moral hazard, the structure of funding, loan pricing, commercial banks, investment banks 


\section{INTRODUCTION}

Loan pricing is a critically important topic in the study of financial institutions (Swank, 1996). Smith (1980) develop the loan pricing balance model based on option pricing theory and later were empirically tested by Booth (1992). Booth also analyzes factors related to contract cost i.e.: cross monitoring hypothesis and financial contract cost hypothesis, to further develop the previous basic model. Empirical study done in USA and Europe found several factors affecting loan pricing decisions i.e.: maturity (Gottesman and Roberts, 2002), non-price term of loans (Strahan, 1999); asymmetric information and moral hazard (Diamond, 1984; Berlin and Mester, 1992; Petersen and Rajan, 2002), legal issue (La Porta, et. al., 1997), pricing decisions for multi-products, regulation (McCauley and Seth, 1992), cross-monitoring (Booth, 1992; Chen, et al., 2000), creditor's characteristic (Coleman, et al., 2002), type of creditor, both domestic and foreign creditor (Chen, et al., 1996; Smith, 2003; Carey and Nini, 2003; Nini, 2004), creditor's reputation (Halak, 2002), type of creditor, both commercial and investment bank (Harjoto, et al.,2000), credit risk and collateral (Booth and Chua, 1995). Several factors mentioned above are using credit risk concept, adverse selection caused by asymmetric information, and moral hazard caused by agency problems (Sinkey, 2002; Heffernan, 1996).

Asymmetric information and moral hazard theories are the most important theories affecting variables in loan pricing decision (Sinkey, 2002; Heffernan, 1996). This research will develop new variables based on asymmetric information and moral hazard theories that play important role in Asia corporate for loan pricing, especially in Indonesia, to improve the basic model by Smith (1980). The basic model development also input the equity structure theory that never been used before for research in USA, Europe, and Asia. The main purpose of this research is to test whether asymmetric information, moral hazard, and equity structure theories affecting the loan pricing decision in Indonesia corporate by developing suitable new variables for Indonesia's characteristic.

In Indonesia, asymmetric information become a serious issue related to the weakness of financial system regulation, insufficient monitoring system from creditor, and the non existence of Independent rating institution to give rating on Private debts by financial institutions. This situation create unique aspect for loan pricing research in Indonesia caused by high level of asymmetric information, which is different from the previous research done in USA and Europe with low level of asymmetric information.

One of the important factors affecting loan pricing is asymmetric information between debtor and creditor. This situation happen since debtor has better information regarding corporate performance compare to the information owned by creditor. The limited information make the creditor unable to differentiate between good and bad debtor and make a mistake by charging high loan pricing for good debtor, or vice versa, called as adverse selection caused by asymmetric information. As a consequence of asymmetric information, the creditor will give high interest rates for debtor that have high asymmetric information issue, and give a interest rates for debtor that have low asymmetric information issue. This will also lead to creditor action to charge a lower loan pricing (debtor's risk is assumed to be constant) if they could decrease the level of asymmetric information, since the risk is also lower compare to the creditor that unable to 
decrease the level of asymmetric information.

One of the variables related to asymmetric information is the type of creditor institution, commercial bank and investment bank. Types of investment bank include investment bank, securities institution, and foreign company (the last two are the majority investment bank in Indonesia). Previous study shows that legal entity bank creditor (commercial bank) have a better information compare to legal entity non bank creditor (James, 1987; Datta et al., 1999; Roten, et al., 2002; Harjoto et al., 2004). In other words, commercial bank creditor have a lower asymmetric information compare to non bank creditor, which mean a commercial bank creditor tend to charge a lower loan pricing compare to the charge made by non bank creditor. Commercial bank ability to minimize the asymmetric information better than non bank creditor is because as a bank they could supervise the cash flow and financial condition of the debtor based on the debtor's account in the bank. While this advantage can not be applied for non bank creditor.

Another important factor in asymmetric information is company owner factor, both for creditor or debtor. Publicly owned company will caused a lower asymmetric information and monitoring cost, as well caused a lower risk, since the debtor maintain their transparency which results in a lower/ cheaper loan pricing (Booth, 1992). Publicly owned bank/ non bank creditor will also lead to more efficient and transparent management, which mean the company have a lower operational cost and tend to create a product with a cheaper and competitive price, and in the end will provide a lower loan pricing.

Gunarsih (2003) found that for manufacture industry, foreign owned company have a better management performance. Similar situation also found for financial institution (creditor), as long as the foreign parent company/ investor have the adequate experience, resources, information system, and control authority that make them able to manage the risk (Swandari, 2004). Using those advantage, foreign creditor could lower asymmetric information level between creditor and debtor, which lead the foreign creditor to give a lower loan pricing, compare to domestic creditor (debtor's risk is assumed to be constant).

This research also discussing moral hazard problem that caused by agency issue. Two main reason are because the goal differences between agent and principal, and also the challenge for principal to identify and verified agent's activities.

In loan pricing, agency problems can emerge in two situations. The first one, agency problems in debtor's company can trigger new agency conflict between creditor and debtor after loan is granted. While the second situation happen between depositor and creditor/ debtor. The first situation could happen between stakeholders in a company that will cause high moral hazard risk and agency cost. In this case, the potency of creditor and debtor agency conflict will be higher if the loan is granted, which means the creditor will give a higher loan pricing as a compensation for high moral hazard risk and agency cost.

The second situation of agency problems happens in a situation where the creditor and debtor are owned by the same shareholder. This will lead to creditor's action to charge a lower loan pricing, which did not reflect the real debtor's risk. When the price did not match the real risk, then the creditor and depositor will bear debtor's risk and caused the depositor to bear unequal risk compare to the interest rate they received. The agency problems between depositor and creditor/ debtor will increase moral hazard 
level from the creditor and debtor to the depositor from the creditor's company.

Moral hazard also play an important role in government owned corporations, both for debtor and bank and non bank creditor. Previous study showed that government owned corporations tend to have higher moral hazard and perquisites issues compare to non government owned corporations (Shapiro and Willig, 1990; Boycko, et al., 1996; Shleifer and Vishnny, 1994), which will finally increase the risk and loan pricing. It is also supported by credit embezzled scandals in government owned company like BAPINDO (Bank Pembangunan Indonesia) case, BBD (Bank Bumi Daya) case and in other non bank government owned corporations. Another fact from inefficiency and moral hazard problems that happend in government owned corporations is the high level of NPL. Per July 1997, the NPL level for government owned bank is 13,8\%, Private owned bank is $4,8 \%$, and foreign owned bank is $4,7 \%$ (Husnan, 2001). The high risk is caused by agency problems since there is no clarity between principal and agent. The other factor is political elite conflict of interest caused a severe inefficiency in government owned bank or government owned financial institutions, results in high price financial products for consumer.

Moral hazard also emerges when creditor and debtor are involved in a special relationship in the same business group. This research will test the loan pricing decision if creditor and debtor are involve in a special relationship in the same business group. Since the special relationship will decrease the level of asymmetric information, then the loan pricing will also be cheaper/ lower. In the contrary, when there is no special relationship between creditor and debtor, the higher level of asymmetric information will lead to more expensive/ higher loan pricing.
But the empirical phenomena in Indonesia showed that conglomerate owned bank tend to do moral hazard by giving low price credit to company inside their business groups (internal capital market) (Husnan, 2001; Fane and McLeod, 2002). The low price credit will trigger overinvestment to the companies in business groups, since the availability of extra fund will motivate debtor to invest in negative NPV portfolio. It showed that the special relationship between creditor and debtor will make the loan pricing decision no longer reflect the risk, which means that cheaper loan pricing granted by creditor is insufficient compare to the high risk level of the debtor.

Based on the previous argument, it is plain to see that for Asia Pacific region, asymmetric information and moral hazard are the most important factors affecting loan pricing, since it could impact in risk variable and agency cost. The higher agency cost will also increase the loan risk and affecting loan pricing decision.

The other important issue in this research is about bank financing structure. In general, bank or financial institution financing structure are dominated by third party funding, so that we need to pay more attention on third party financing structure since it might affects banks' cost of equity.

Commercial bank financing structure can be divided into two types based on the cost of equity level placed in commercial bank by the third party. The first one is term deposit that has a higher funding cost, and the second one is saving account or demand deposit that relatively has a lower funding cost. The proportion between term deposit and saving account/ demand deposit might affect banks' cost of equity. The higher term deposit proportion in creditor funding, lead to higher bank's cost of equity, which results in higher loan pricing decision charged by commercial bank. 


\section{LITERATURE REVIEW}

\subsection{Creditor Institution Type}

There are crucial differences between comercial bank and investment bank that could imply on loan pricing decision (Carey, Post, Sharpe, 1998; Harjoto et al., 2000). The differences are: firstly, commercial bank fund came from relatively cheap and stable deposit (James, 1987). Second, the government regulate a limit on investment bank fund utilization that impact on commercial bank profit from lending activities to a debtor. Third, relationship banking could be one of the solutions to solve agency problem. Moral hazard, and adverse selection between creditor and debtor. Fourth, with several product varieties, commercial bank able to minimize monitoring cost since it is unnessecary to take monitoring action to debtor for new product (Drucker and Puri, 2003). Fifth, in accounting, investment bank is obliged to apply mark to market rules, while in the contrary, commercial bank do not have the same obligation (Harjoto, et al., 2000). In conclusion, based on the explanation above, commercial bank have a better ability to reduce assymmetric information compare to investment bank that will lead to a cheaper loan pricing decision.

$\mathrm{H}_{1}$ : Commercial bank offer a lower loan pricing compare to investment bank

\subsection{Foreign and Domestic Ownership (Creditor)}

Several articles stated that foreign owned bank have a modern information technology and high performing human capital (Buch, 1997), make them able to provide an efficient service to their customers (Nikiel and Opiela, 2002), provide best price, high quality varieties product (Levine, 1996), have a better measurement, supervision, and risk management system
(Gleassner and Oks, 1994), higher efficiency (Hasan and Marton, 2003; Grigorian and Manole, 2002; Fries and Taci, 2005) and finally it is stated that foreign owned bank performance is better than domestic owned bank (Bonin, et al., 2005) and they will use their capability to detect and measure the risk of Indonesian companies and offer a lower loan pricing compare to domestic creditor.

$\mathrm{H}_{2}$ : Foreign creditor will offer a lower loan pricing compare to domestic creditor

\subsection{Public Ownership}

Public owned company publicly traded their shares in stock exchange. Part of their obligation is to provide periodic report to stock exchange authority to ensure the transparency and monitoring by public. This situation create a lower assymmetric information compare to non public ownership company.

If the debtor could lower the assymmetric information level, then the creditor will offer a cheaper loan pricing. Booth (1992) also explain that creditor will offer a lower loan pricing for public owned company, since they could take advantage from public, analyst, rating agencies cross monitoring activities, to reduce their monitoring cost.

Public monitoring will also affecting the creditor behavior. The same case for debtor also apply for creditor, public ownership will reduce the agency cost and moral hazard level, and the efficiency will give maximum profit for shareholders. Public companies become more competitive, both in price and service, because of the cost efficiency. This situation lead to an understanding that public owned creditor will have a better performance and efficiency compare to private owned company, since they offer a cheaper product and service. 
$\mathrm{H}_{3}$ : Loan pricing for public owned company debtor will be lower compare to non public owned company debtor

$\mathrm{H}_{4}$ : Public creditor will offer a lower loan pricing compare to non public creditor

This research also assumes that public owned creditor or debtor will cause an effective cross monitoring activities to reduce assymmetric information level and loan pricing in debtor company or inprove the efficiency level in creditor company.

$\mathrm{H}_{5}$ : The higher public ownership in debtor company will results in a lower loan pricing

$\mathrm{H}_{6}$ : The higher public ownership in creditor company will results in a lower loan pricing

\subsection{Government Ownership}

Theoritically, public ownership through government could improve efficiency (Laffont and Tirole, 1993; Sappington and Stiglitz, 1987). But based on empirical study, it is found that government owned company is less efficient compare to private owned company (Shleifer and Vishnny, 1997). Government owned company is not control by the public, but controlled by bureaucrat with political interest and not for public welfare (Shapiro and Willig, 1990; Boycko, et al., 1996; Shleifer and Vishnny, 1994). But even though inefficiency occurs in government owned company, the government budget will be use to compensate the loss (Kikeri, et al., 1992; Boycko, et al.,1995).

Empirical study towards government owned bank performance found a similar fact that government owned bank is less efficient compare to private owned bank (Bonin, et al., 1998; Buch, 1997). But in the other side, government owned bank also have a cheaper funding resources on behalf of public interest.
$\mathrm{H}_{7}$ : Loan pricing for government debtor will be lower compare to non government debtor, since there is no bankruptcy risk for government owned company

$\mathrm{H}_{8}$ : Government creditor will offer a lower loan pricing compare to non government creditor, since they have access to a cheaper funding resources

\subsection{Special Relationship between Creditor and Debtor}

The special relationship occurs when both creditor and debtor are owned by the same ultimate shareholder. If creditor and debtor have a special relationship, the loan should have a lower asymmetric information level and monitoring cost, that will results in a cheaper loan pricing.

But the empirical phenomenon in Indonesia shows that conglomerate owned bank is tend to perform moral hazard by granted cheap credit to company inside their business group (Husnan, 2001; Fane and McLeod, 2002). There is also tendency to overinvestment in company inside their business group, since funding resources are cheap and excessive, which will lead to investment on a negative NPV.

$\mathrm{H}_{9}$ : The existence (nonexistence) of special relationship between creditor and debtor will cause to a lower (higher) loan pricing

\subsection{Funding Resources and Cost of fund \\ The primary funding resources for} commercial bank are core deposits and managed liabilities (purchased funds), with total contribution around $90 \%$ of commercial bank total fund, and the other $10 \%$ came from equity capital.

Fund from core deposit have a lower interest rate, lower volatility rate, and more sensitive to interest rate compare to fund 
from managed liabilities (Sinkey, 2002). This means that bank liabilities composition play a big role in affecting the bank cost of fund, when the managed liabilities composition is bigger than core deposit, then the interest rate that need to be paid by the bank will be higher, along with the bank cost of fund and loan pricing.

$\mathrm{H}_{10}$ : There is a positive correlation between bank cost of fund with loan pricing offered by the bank

\subsection{Control Variables}

Shorter term maturity rate will give a chance for creditor to reevaluate or remonitoring when the loan is due, which mean there is positive correlation between maturity rate with debtor's quality (Barclay and Smith, 1995; Stoch and Mauer, 1996). We can conclude that longer term maturity rate means a lower loan pricing and also shows that the debtor have a better information quality.

Another tools for monitoring is the type of loan, in this case the term loan which usually are given to high risk debtor caused by high asymmetric information level, while in the contrary line credit usually are given to low risk debtor with low asymmetric information level (Marciano, 2003).

Concerning collateral role, theoretically it reflects low risk debtor (with low asymmetric information level) but empirical study showed that collateral reflects high risk debtor (with high asymmetric information level).

The creditor will give a lower loan pricing with a bigger amount for debtor with a better quality. And to limit the loss risk, creditor will give a higher loan pricing with a smaller amount for debtor that have a low quality (Smith, 2003; Millon and Thakor, 1985; Datta, Iskandar Datta, Patel, 1998).

Monitoring also play an important role, since it reflects good reputation and the higher loan pricing granted. Some researches use market share as a proxy to measure reputation (Gande, et al., 1997; Mullineaux and Roten, 2000).

Central bank regulation for banking sector also might affect loan pricing decision. One of the crucial regulation is capital constraints regulation about lending limit and capital requirement. Those limitations will affect bank decision to granted a credit and third party capitalization and the creditor will put a higher loan pricing as a new requirement to balance higher capital constraints owned by the creditor (Coleman et al., 2002; Chen et al., 1996; Hao, 2003).

Loan risk is closely related to debtor's characters. Several characteristics that may affect risk loan are (1) financial performance (leverage, size, current ratio, and profitability), (2) industry type, (3) loan purpose (John, Lynch, and Puri, 2003; Gande at al., 1997; Booth and Booth, 2002).

\section{DATA AND SAMPLE}

There are four data resources for this research, which are: first, Deal Scan LPC (Loan Pricing Corporation). Second, Indonesia Banking Directory for all data related to commercial bank in Indonesia. Third, Capital Market Directory for all data related to public owned companies in Indonesia. Fourth, Top Companies and Big Group in Indonesia $7^{\text {th }}$ edition, published by PT. Kompas Indonesia. The research period is vefore 1997 economic crisis, which is during 1990-1997. 


\section{VARIABLE OPERATIONAL DEFINITION}

Variable operational definition is shown in Table 1.

Table 1.

Variable Operational Definition

\begin{tabular}{|c|c|c|c|c|}
\hline No & Variable Code & $\begin{array}{l}\text { Variable } \\
\text { Type }\end{array}$ & $\begin{array}{l}\text { Measurement } \\
\text { Scale }\end{array}$ & Note \\
\hline 1 & SPREAD & Dependent & Ratio & Loan interest rate/ loan pricing is above LIBOR \\
\hline 2 & ALL_IN & Dependent & Ratio & Loan pricing with additional fee \\
\hline 3 & "BANK_KOM & Independent & Nominal & Commercial bank as creditor institution \\
\hline 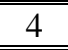 & LEN_FOREIGN & Independent & Nominal & Foreign owned creditor \\
\hline 5 & LEN_PRIVATE & Independent & Nominal & Privatee domestic owned creditor \\
\hline 6 & LEN_PUBLIC & Independent & Nominal & Public domestic owned creditor \\
\hline 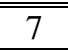 & LEN_GOV & Independent & Nominal & Domestic government owned creditor \\
\hline 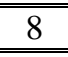 & "BOR_PUBLIC & Independent & Nominal & Public domestic owned debtor \\
\hline 9 & BOR_GOV & Independent & Nominal & Government domestic owned debtor \\
\hline 10 & PUBLIC_OWN(K) & Independent & Ratio & Public own percentage in creditor's institution \\
\hline 11 & PUBLIC_OWN(D) & Independent & Ratio & Public own percentage in debtor’s institution \\
\hline 12 & RELATIONSHIP & Independent & Nominal & Special relationship between creditor and debtor \\
\hline 13 & RATIO CD/ML & Independent & Ratio & $\begin{array}{l}\text { Ratio Core Deposit (CD) and Managed } \\
\text { Liabilities (ML) }\end{array}$ \\
\hline 14 & AMOUNT & Var. Kontrol & Ratio & Loan amount \\
\hline 15 & MATURITY & Var. Kontrol & Ratio & Loan maturity \\
\hline 16 & SECURED & Var. Kontrol & Nominal & "Collateral loan \\
\hline 17 & TERM_LOAN & Var. Kontrol & Nominal & Term_loan type \\
\hline 18 & MKT_SHR & Var. Kontrol & Ratio & Market share of creditor \\
\hline 19 & "DEBT_REPAY & Var. Kontrol & Nominal & Debt to repay loan \\
\hline 20 & TAKEOVER & Var. Kontrol & Nominal & Debt to fund take over \\
\hline 21 & "WORK_CAP & Var. Kontrol & Nominal & Debt as working capital \\
\hline 22 & CAR & Var. Kontrol & Ratio & Capital Adequacy Ratio \\
\hline 23 & LR & Var. Kontrol & Ratio & Loan ratio and creditor's assets \\
\hline 24 & "SIC_1-SIC_9 & Var. Kontrol & Nominal & Industry code to show debtor's industry type \\
\hline 25 & Y94-Y97 & Var. Kontrol & Nominal & Year of Contract Deal \\
\hline
\end{tabular}

\section{TESTING MODEL}

\subsection{Test for Loan Pricing}

In this testing, each model will be tested 3 (three) times with a different sample and sub sample, consist of: (1) The whole sample, (2) Sample for debtor in financial industry, (3) Sample for creditor in financial industry. The OLS regression models with white correction are:

- LoanSpread (all in) = f[Maturity, Credit type, Collateral, LoanSize, Creditor's reputation, Industry type, Loan purpose, Period] 
- LoanSpread (all in) = f[Institution type, Ownership(Foreign/Domestic), Maturity, Credit type, Collateral, LoanSize, Creditor's reputation, Industry type, Loan purpose, Period]

- LoanSpread (all in) = f[Institution type, Ownership(Public, Private, Government), Maturity, Credit type, Collateral, LoanSize, Creditor's reputation, Industry type, Loan purpose, Period]

- LoanSpread (all in) = f[Institution type, Ownership(Public,Private, Government), Hubungan, Maturity, Credit type, Collateral, LoanSize, Creditor's reputation, Industry type, Loan purpose, Period] $\rightarrow$ sub sample from domestic creditor

- LoanSpread (all in) = f[Institution type, Public's percentage, Relationship, Maturity, Credit type, Collateral, LoanSize, Creditor's reputation, Industry type, Loan purpose, Financial performance (Leverage, total assets, current assets, profitability), Period] $\rightarrow$ sub sample from public debtor

- LoanSpread (all in) = f[Institution type, Public's percentage Relationship, Relationship, Maturity, Credit type, Collateral, LoanSize, Creditor's reputation, Industry type, Loan purpose, Period] $\rightarrow$ sub sample from public creditor

- LoanSpread (all in) = f[Public's percentage, Relationship, Maturity, Credit type, Collateral, LoanSize, Creditor's reputation, Industry type, Loan purpose, FinancialPerformance(Leverage, total assets, current assets), Cost of fund, Regulation(Lending Ratio,Capital Requirement Ratio), Period] $\rightarrow$ sub sample from public debtor and domestic commercial bank creditor

\subsection{Test for Different Loan Pricing}

There will be equality test of regression coefficient from each variable for several samples divided based on creditor institution type and creditor ownership like what Paternoster et al (1998) did.

- Testing equality test of regression coefficient between commercial bank creditor sub sample and investment bank sub sample.

- Testing equality test of regression coefficient between foreign owned bank creditor sub sample and domestic owned bank creditor sub sample.

- Testing equality test of regression coefficient for interaction model sub sample, domestic investment bank, domestic commercial bank, foreign investment bank and foreign commercial bank.

\section{ANALYSIS}

\subsection{Test for Model 1}

Regression test for model 1 is using control variables without considering main variables (Table 2.). AMOUNT variable is significant in $1 \%$ level with negative regression coefficient, which aligns with the hypothesis that the loan amount is one of the instruments from creditor to limit their loss. Maturity variable shows a significant positive regression value in $1 \%$ level, which aligns with the hypothesis about interest rate. SECURED variable shows a significant positive value in $1 \%$ level for all samples, which means that the lower debtor's quality (the higher debtor's risk) will make the creditor asking for collateral, in the contrary, the creditor tend not asking for collateral if the debtor's quality is higher (debtor's risk is lower). TERM_LOAN variable is significant positive for all three samples but with various level of significant, shows that creditor use type of loan to perform loan monitoring by giving term loan for debtor with low quality (high risk), while giving line credit for debtor with high quality (low 
risk). Creditor's market share variable shows a consistent negative value in all samples, but with only $5 \%$ significant level in all samples and financial sample. Presumable, the better creditor's reputation shows a better long term performance, a better capability to reduce asymmetric information, showed by more precise pricing decision.

Table 2.

Regression Test of Model 1

\begin{tabular}{|c|c|c|c|c|c|c|}
\hline \multirow[t]{2}{*}{ Variable } & \multicolumn{3}{|c|}{ SPREAD } & \multicolumn{3}{|c|}{ SPREAD ALL IN } \\
\hline & ALL & Non Fin & Fin & ALL & Non Fin & Fin \\
\hline $\mathrm{C}$ & $433,5874 * * *$ & $367,7493 * * *$ & $484,2005 * * *$ & $456,8355^{* * *}$ & $371,0771 * * *$ & $584,4229 * * *$ \\
\hline LOG(AMOUNT) & $\begin{array}{c}- \\
15,98583 * * *\end{array}$ & $\begin{array}{c}- \\
16,28984 * * *\end{array}$ & $\begin{array}{c}- \\
15,88057 * * *\end{array}$ & $\begin{array}{c}- \\
14,26019 * * *\end{array}$ & $\begin{array}{c}- \\
14,50609 * * *\end{array}$ & $\begin{array}{c}- \\
15,49253 * * *\end{array}$ \\
\hline LOG(MATURITY) & $15,14003^{* * *}$ & $19,92508 * * *$ & $-4,210816$ & 7,675763 & $13,32823 *$ & $-14,86174 *$ \\
\hline SECURED & $49,66318 * * *$ & $50,86764 * * *$ & $44,47998 * * *$ & $59,45357 * * *$ & $59,54441 * * *$ & $57,87775 * * *$ \\
\hline TERM_LOAN & 9,053836* & $19,01269 * * *$ & $-20,11903 * *$ & $12,29807 * *$ & $24,03936 * * *$ & $-20,30444 * *$ \\
\hline MARK_SHR & $-99,97440 * *$ & $-89,56913$ & $-201,7352^{* *}$ & $\begin{array}{c}- \\
204,8397 * * *\end{array}$ & $-176,8930 * *$ & $\begin{array}{c}- \\
309,4039 * * *\end{array}$ \\
\hline DEBT_REPAY & $-1,121723$ & 0,573299 & $-1,843950$ & $-1,835199$ & 0,664106 & $-10,31990$ \\
\hline TAKEOVER & 24,64703 & 23,91901 & - & 9,459141 & 8,252259 & - \\
\hline WORK_CAP & 3,495120 & $-1,822010$ & 7,441798 & 3,182773 & $-5,584467$ & 8,313055 \\
\hline SIC_1 & $-15,08169$ & $-19,36558$ & - & $-22,51908$ & $-26,23072 *$ & - \\
\hline$\overline{\text { SIC_2 }}$ & $\begin{array}{c}- \\
26,41420 * * *\end{array}$ & $\begin{array}{c}- \\
26,76730 * * *\end{array}$ & - & $-22,69827 * *$ & $-22,19752 * *$ & - \\
\hline SIC_3 & $\begin{array}{c}- \\
26,50782 * * *\end{array}$ & $-25,28847 * *$ & - & $-18,01490$ & $-16,52945$ & - \\
\hline SIC_4 & $\begin{array}{c}- \\
51,34685^{* * *} \\
\end{array}$ & $\begin{array}{c}- \\
53,83491^{* * *} \\
\end{array}$ & - & $\begin{array}{c}- \\
40,33683^{* * *} \\
\end{array}$ & $\begin{array}{c}- \\
42,18393 * * * \\
\end{array}$ & - \\
\hline SIC_5 & $\begin{array}{l}-22,15667^{*} \\
\end{array}$ & $-21,55365^{*}$ & - & -30,79988** & -28,77948** & - \\
\hline 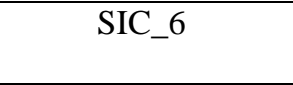 & $\begin{array}{c}- \\
60,91774 * * *\end{array}$ & - & - & $\begin{array}{c}- \\
47,24296 * * *\end{array}$ & - & - \\
\hline SIC_7 & 16,61560 & 11,73693 & - & 29,79940* & 24,90956 & - \\
\hline "SIC_8 & $\begin{array}{c}- \\
56,18286^{* * *} \\
\end{array}$ & $-54,60684 *$ & - & $\begin{array}{c}- \\
63,79912^{* * *} \\
\end{array}$ & $-58,34837 * *$ & - \\
\hline Y93 & $-2,480603$ & $69,89080^{* * *}$ & $-40,38281 *$ & $-12,98482$ & $67,08629 * * *$ & $\begin{array}{c}- \\
68,71025 * * * \\
\end{array}$ \\
\hline Y94 & $-21,94636$ & 26,08612 & $-50,60034^{* *}$ & $-24,10016$ & 35,33546 & $\begin{array}{c}- \\
77,16020 * * * \\
\end{array}$ \\
\hline Y95 & $-37,71355 * *$ & 10,74911 & $\begin{array}{c}- \\
63,13250 * * * \\
\end{array}$ & $-46,71973 *$ & 14,94371 & $\begin{array}{c}- \\
98,54988 * * * \\
\end{array}$ \\
\hline Y96 & $\begin{array}{c}- \\
46,84295^{* * *} \\
\end{array}$ & $-5,946604$ & $-54,63373 * *$ & $-51,01065^{* *}$ & 6,152331 & $\begin{array}{c}- \\
91,17500 * * * \\
\end{array}$ \\
\hline Y97 & $-36,32139 * *$ & 8,591296 & $-51,89303 * *$ & $-47,62888 * *$ & 11,57830 & $\begin{array}{c}- \\
89,69273 * * * \\
\end{array}$ \\
\hline $\mathrm{N}$ & 609 & 421 & 188 & 566 & 380 & 186 \\
\hline Adj. $\mathrm{R}^{2}$ & $\begin{array}{l}0,352011 \\
\end{array}$ & 0,284891 & 0,192302 & 0,313296 & 0,272115 & $\begin{array}{l}0,239741 \\
\end{array}$ \\
\hline F Value & $16,72796 * * *$ & 9,366147*** & 4,710183*** & $13,27482 * * *$ & 8,084341*** & 5,861499*** \\
\hline
\end{tabular}


In purpose of loan variable shows that creditor did not consider risk of purpose of loan as a significant factor that could affect loan pricing. For non financial company sample, almost all industries variable shows a significant value, but in all period variable the results is insignificant. In the contrary, for financial company sample, all period variable shows a significant value.

\subsection{Test for Model 2}

Analysis for model 2 (Table 3.) will be focusing in main variables and regression analysis in this research.

Table 3.

Regression Test of Model 2

\begin{tabular}{|c||c||c|c|c|c||c|}
\hline \multirow{2}{*}{ Variable } & \multicolumn{3}{c|}{ SPREAD } & \multicolumn{3}{c|}{ SPREAD ALL IN } \\
\cline { 2 - 7 } & ALL & NON FIN & FIN & ALL & NON FIN & FIN \\
\hline \hline COMM_BANK & $-3,202768$ & $-11,84891^{*}$ & $13,09354^{* *}$ & $-8,894991$ & $-17,26614^{* *}$ & 6,788512 \\
\hline \hline FOR_CRED & - & - & - & - & - & - \\
& $79,21886^{* * *}$ & $85,23165^{* * *}$ & $56,62751^{* * *}$ & $91,42382^{* * *}$ & $98,37479^{* * *}$ & $68,93692^{* * *}$ \\
\hline \hline PUBLIC_BOR & $-1,343878$ & $-0,057954$ & $-7,650832$ & 0,594653 & 1,174961 & $-1,728245$ \\
\hline \hline GOV_BOR & - & $-38,26868$ & $-26,12875^{* *}$ & - & $-28,40778$ & - \\
& $39,04858^{* * *}$ & & & $42,06889 * * *$ & & $31,69714^{* * *}$ \\
\hline \hline $\mathrm{N}$ & 609 & 421 & 188 & 566 & 380 & 186 \\
\hline \hline Adj. $\mathrm{R}^{2}$ & 0,482767 & 0,438169 & 0,292742 & 0,462460 & 0,438043 & 0,339125 \\
\hline
\end{tabular}

Institution type variable which is BANK_KOM shows unstable result. For non financial sample shows a significant negative relationship in $10 \%$ level between commercial bank and spread, which proved hypothesis no.1. But for financial company sample, shows a contradictive result with significant positive regression coefficient in 5\% level. Presumable, commercial bank have a better reputation than investment bank, which lead to debtor action to borrow from commercial bank although they offer a higher price, based on signal theory.

Interesting part of the test result, the foreign creditor variable shows a negative significant coefficient consistently for all samples. The negative relationship shows that foreign creditor grant a lower loan pricing compare to domestic creditor. Foreign creditor with good reputation did not give a higher interest rate compare to domestic creditor, but in the contrary set a lower interest rate than domestic creditor, which is supporting the hypothesis no.2.

Debtor ownership test result shows there is no significant loan pricing differences between public and private debtor, although coefficient sign support the hypothesis no.3. It means that even though public creditor have a lower asymmetric information level compare to private creditor, but both institution make the same decision about loan pricing value. Government ownership shows a result that support hypothesis no.7 which is negative significant even though only for all samples and financial sample. It means that government debtor has a lower bankruptcy risk compare to non government debtor, since it is certain that the company will have government's backup.

But generally, institution type and ownership variables cause a better pricing model. It can be seen from the rise of adjusted R2 for about $10 \%-15 \%$ (the 
comparison of adjusted $\mathrm{R}^{2}$ between model 1 and model 2).

\subsection{Test for Model 3}

Model 3 is an elaboration from model 2. The differences are located in creditor ownership variable, where model 2 only have foreign and domestic ownership, meanwhile in model 3 domestic ownership is divided into public, private, and government ownership, and foreign ownership will be omitted to constant. Model 3 development is necessary to see the loan pricing differences between public, private, government ownership that use foreign loan pricing as a reference.

Regression test result for model 3 (spread) can be seen in table 4. Several hypotheses are consistent with some of the results. Domestic creditor ownership that has been breakdown into public, private, government creditor ownership are align with predicted theory. The bps differences between foreign public and foreign private shows that implicitly private creditor is generally set a higher loan pricing compare to public creditor.

Table 4.

Regression Test of Model 3

\begin{tabular}{|c||c||c|c||c|c|c|}
\hline \multirow{2}{*}{ Variable } & \multicolumn{3}{|c|}{ SPREAD } & \multicolumn{3}{c|}{ SPREAD ALL IN } \\
\cline { 2 - 7 } & ALL & NON FIN & FIN & ALL & NON FIN & FIN \\
\hline \hline COMM_BANK & 1,131618 & $-6,701966$ & $15,18572^{* *}$ & $-5,967267$ & $-13,49005^{*}$ & 8,563765 \\
\hline \hline LEN_PUBLIC & $86,66556^{* * *}$ & $95,09362^{* * *}$ & 36,61765 & $109,6961^{* * *}$ & $117,5053^{* * *}$ & $72,99657^{* *}$ \\
\hline \hline LEN_PRIVATE & $126,3112^{* * *}$ & $157,9603^{* * *}$ & $71,85292^{* *}$ & $119,1327^{* * *}$ & $141,9724^{* * *}$ & $83,57860^{* *}$ \\
\hline \hline LEN_GOV & 8,200163 & $-29,18760$ & $53,37221^{* * *}$ & 14,11110 & $-18,82007$ & $52,69949^{* *}$ \\
\hline \hline BOR_PUBLIC & $-0,819741$ & $-0,039864$ & $-7,886396$ & 0,662859 & 0,617979 & $-1,691335$ \\
\hline \hline GOV_BOR & - & $-4,144334$ & $-26,79852^{* *}$ & - & 4,337729 & - \\
& $29,36772^{* * *}$ & & & $32,13502^{* * *}$ & & $29,73082^{* *}$ \\
\hline N & 609 & 421 & 188 & 566 & 380 & 186 \\
\hline \hline Adj. $\mathrm{R}^{2}$ & 0,517247 & 0,513042 & 0,290124 & 0,497036 & 0,501782 & 0,335728 \\
\hline \hline
\end{tabular}

Based on regression test from model 1 until model 3, several conclusion arise: first, spread as a loan pricing proxy is generally better than spread all in (spread with additional fees). Second, institution type and ownership variables have a significant influence in loan pricing. Third, loan pricing model with institution type and ownership variables addition, is better than standard loan pricing model (model 1). Fourth, institution type and ownership variables are generally consistent with several hypotheses proposed in this research.

\subsection{Test for Model 4}

Data structure for model 4 is a little different with the previous models. It is because the purpose of model 4 test is to specifically assets special relationship variable between creditor and debtor.

Sample that are being use in model 4 test have special characteristic related to the purpose of the test, where loan transaction is done by creditor or syndicate with at least one domestic arranger. 
Table 5.

Regression Test of Model 4

\begin{tabular}{|c||c|c|c|c|c||c||}
\hline \multirow{2}{*}{ Variable } & \multicolumn{3}{|c|}{ SPREAD } & \multicolumn{3}{c||}{ SPREAD ALL IN } \\
\cline { 2 - 7 } & ALL & NON FIN & FIN & ALL & NON FIN & FIN \\
\hline \hline COMM_BANK & $33,57606^{*}$ & 9,934644 & 31,81939 & 20,54663 & 9,692566 & $-27,89267$ \\
\hline \hline RELATIONSHIP & 1,857628 & 8,697366 & $-41,50190$ & 14,85449 & 47,26001 & $-52,29220$ \\
\hline LEN_PUBLIC & $58,97603^{* * *}$ & $73,28183^{* * *}$ & $-0,019094$ & $83,88749^{* * *}$ & $99,62705^{* * *}$ & 36,36426 \\
\hline LEN_PRIVATE & $129,3348^{* * *}$ & $143,5024^{* * *}$ & 77,42237 & $117,9475^{* * *}$ & $135,0926^{* * *}$ & 44,10820 \\
\hline \hline LEN_GOV & $-42,50744 *$ & $-63,10921^{* *}$ & $-14,96943$ & $-42,00823^{* *}$ & $-53,02871^{* *}$ & $-25,03331$ \\
\hline \hline BOR_PUBLIC & $-16,37472$ & $-20,61624$ & $-37,19394$ & $-14,43404$ & $-22,43287$ & $-38,40926$ \\
\hline \hline BOR_GOV & 13,95235 & $-52,38635$ & 36,27112 & 21,10225 & $-18,69910$ & 46,17683 \\
\hline \hline N & 167 & 125 & 42 & 154 & 112 & 42 \\
\hline \hline Adj. $\mathrm{R}^{2}$ & 0,565998 & 0,547240 & 0,188959 & 0,558024 & 0,538782 & 0,262947 \\
\hline
\end{tabular}

Test for model 4 (spread) as seen in table 5. shows that statistically RELATIONSHIP variable is insignificant and have no differences than nil. This result is consistent for all samples. It means that special relationship between creditor and debtor did not influence loan pricing decision. It is not proven that special relationship or affiliation relationship between creditor and debtor will lead to moral hazard action by giving a cheaper loan pricing.

Generally, model 4 (spread) is better than the previous models by having a higher adjusted $\mathrm{R}^{2}$ value. Adjusted $\mathrm{R}^{2}$ value for model 4 (spread) is $56,59 \%$ for all samples and $54,72 \%$ for non financial sample. It shows that homogeneous sample provide a better prediction and test result.

\subsection{Test for Model 5}

Model 5 test is focused in public companies sample to check whether debtor's financial ratio variable could affect loan pricing decision. Financial variables are consist leverage variable (D/TA), liquidity (CA/CL), company size (Total Assets) and profitability (EBIT/TA).

From four financial ratio variables, leverage, liquidity, log (Total Asset), and profitability (EBIT/TA), only two significant variables for loan pricing, which are log (TA) and profitability (EBIT/TA). The log (TA) variable represent the company size, where for overall samples test the result shows negative significant regression coefficient in $1 \%$ level. Big company tend to have smaller risk and asymmetric information problem compare to smaller company, that make creditor set a lower loan pricing (Smith, 2003; Millon and Thakor, 1985; Data, et al, 1998). But in sub sample test, we can see that log (TA) only significant for financial company sub sample. It is align with several financial institution studies say that "In Financial Industry, Size Does Matters”. 
Table 6.

Regression Test of Model 5

\begin{tabular}{|c|c|c|c|c|c|c|}
\hline \multirow{2}{*}{ Variable } & \multicolumn{3}{|c|}{ SPREAD } & \multicolumn{3}{|c|}{ SPREAD ALL IN } \\
\hline & ALL & NON FIN & FIN & ALL & NON FIN & FIN \\
\hline COMM_BANK & -4,898876 & -21,01825* & $25,50450 * *$ & -12,76362 & $-28,92210 * *$ & 14,62328 \\
\hline RELATIONSHIP & -10,25736 & (-3,396637 & $-42,60342 * *$ & 59,48055 & 76,85024 & $\begin{array}{c}- \\
67,1146^{* * *}\end{array}$ \\
\hline PUUBLIC_OWN & 1,230718 & 19,29264 & 3,981235 & $-35,47207$ & $-35,88291$ & 4,740701 \\
\hline LEN_PUB & $66,82658^{* *}$ & $64,54029 * *$ & - & $85,02414^{* * *}$ & $75,03042 * *$ & - \\
\hline LEN_PRIV & $\begin{array}{l}-32,47762 \\
\end{array}$ & - & - & $-121,2427 *$ & - & 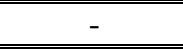 \\
\hline LEN_GOV & 1010,45692 & 10,69477 & - & 2,131543 & $-5,893740$ & $\overline{-1}$ \\
\hline LEV & $-4,264971$ & 24,79203 & -66,61386 & $-14,80833$ & 30,32720 & $\begin{array}{c}- \\
138,0949 * *\end{array}$ \\
\hline LIQ & $-0,425899$ & $-0,626479$ & 1,400206 & 0,337019 & 0,252258 & 0,810012 \\
\hline LOG(TA) & $\begin{array}{c}- \\
10,06627 * * * \\
\end{array}$ & $-6,510255$ & $\begin{array}{c}- \\
12,03844^{* * *} \\
\end{array}$ & $-7,430778 * *$ & $-2,116226$ & $\begin{array}{c}- \\
12,11670 * * \\
\end{array}$ \\
\hline EBIT/TA & $\begin{array}{c}- \\
54,31331^{* * *} \\
\end{array}$ & $\begin{array}{c}- \\
34,98323^{* *} \\
\end{array}$ & $-11,92061$ & $-74,2117^{* * *}$ & $\begin{array}{c}- \\
56,96939 * * * \\
\end{array}$ & $-198,6594$ \\
\hline $\mathrm{N}$ & 222 & 143 & 79 & 213 & 136 & 77 \\
\hline Adj. $\mathrm{R}^{2}$ & 0,433773 & $\begin{array}{l}0,397278 \\
\end{array}$ & 0,435918 & 0,373485 & 0,380992 & 0,372501 \\
\hline
\end{tabular}

Profitability variable shows negative significant regression coefficient in $1 \%$ level. It means that the higher debtor's profitability, the lower loan pricing set by the creditor. Company with high profitability could reduce debtor's loss risk probability to fulfill his obligation based on loan contract agreement. But for sub sample test, profitability variable is only significant for non financial company sub sample, while for financial company sub sample the result is insignificant.

General conclusion for model 5 regression test (Table 6.) are first, public ownership percentage in debtor's company do not have significant influence on loan pricing, the empirical fact did not support hypothesis no.5. Second, creditor only use part of financial ratio to make decision on loan pricing while the creditor use a different financial ratio to decide loan pricing for financial and non financial sector of debtor's company. Third, in general, model 5 using spread as dependent variable is once again better than model 5 with spread all in (spread with additional value) as dependent variable.

\subsection{Test for Model 6}

Model 6 test is done to check hypothesis no.6 about public ownership percentage in creditor that play a negative role in loan pricing decision. 
Table 7.

Regression Test for Model 6

\begin{tabular}{|c|c|c||c||c||c|c|}
\hline \multirow{2}{*}{ Variable } & \multicolumn{3}{|c||}{ SPREAD } & \multicolumn{3}{c|}{ SPREAD ALL IN } \\
\cline { 2 - 7 } & ALL & NON FIN & FIN & ALL & NON FIN & FIN \\
\hline \hline RELATIONSHIP & 71,79515 & 25,82683 & - & $269,1505^{* * *}$ & 25,82683 & - \\
\hline \hline PUBLIC_OWN & $169,3306^{*}$ & $181,1974^{* *}$ & - & $186,6708^{* *}$ & $181,1974^{* *}$ & - \\
\hline BOR_PUBLIC & $-89,41700^{*}$ & $-72,59928^{*}$ & - & $-140,850^{* * *}$ & $-72,59928^{*}$ & - \\
\hline \hline $\mathrm{N}$ & 53 & 50 & - & 53 & 50 & - \\
\hline \hline Adj. ${ }^{2}$ & 0,226019 & 0,197399 & - & 0,410955 & 0,197399 & - \\
\hline
\end{tabular}

Test result for model 6 (spread) can be seen in table 7 . and we can conclude that public ownership percentage variable from creditor has positive significant regression coefficient at $10 \%$ level for overall samples, and $5 \%$ level for non financial sample. It shows that the higher public ownership in creditor company, the higher loan pricing set by the creditor. This result is contrast with hypothesis no. 6.

\subsection{Test for Model 7}

Test for model 7 is done to answer hypothesis no.10 about cost of fund (Giro+Tabungan/Deposito $\rightarrow$ saving account and term deposit) from creditor. Hypothesis no.10 stated the positive relationship between cost of fund and loan pricing, the higher cost of fund, the higher loan pricing set by the creditor, and vice versa. This model also test two financial variables regulated by the government from creditor, which are CAR (Capital Adequacy Ratio) and LR (Lending rate).

In tablel 8. we can see the result for GTD variable is negative significant regression coefficient at 5\% level for overall samples, while for non financial sample the result is negative insignificant. This result support hypothesis no.10, where the higher GTD (showing a lower cost of fund from the creditor) lead to a lower loan pricing set by the creditor. But the result is inconsistent in overall test models.

Table 8.

Regression Test of Model 7

\begin{tabular}{|c||c||c|c||c||c|c||}
\hline \multirow{2}{*}{ Variable } & \multicolumn{3}{c|}{ SPREAD } & \multicolumn{3}{c||}{ SPRED ALL IN } \\
\cline { 2 - 7 } & \multicolumn{1}{|c|}{ ALL } & NON FIN & FIN & ALL & NON FIN & FIN \\
\hline \hline RELATIONSHIP & $66,25342^{*}$ & 9,625416 & - & $151,7849^{* * *}$ & $167,9982^{*}$ & - \\
\hline \hline BOR_PUBLIC & $-42,84306$ & $-41,45073$ & - & $-62,83255$ & - & - \\
& & & & & $86,32391^{* *}$ & \\
\hline \hline BOR_GOV & 42,51201 & - & - & $-60,73713$ & - & - \\
\hline \hline LEN_PUB & $-117,3810^{* *}$ & $-76,86316$ & - & $-5,856679$ & 8,605087 & - \\
\hline \hline LEN_GOV & - & - & - & $-154,0513^{* *}$ & $-139,4606^{*}$ & - \\
& $246,4839^{* * *}$ & $250,8041^{* * *}$ & & & & \\
\hline \hline GTD & - & $-41,40758$ & - & $-1,870212$ & $-7,762352$ & - \\
& $69,51882^{* * *}$ & & & & & \\
\hline \hline CAR & 4,812529 & $-12,29934$ & & $-68,15396$ & $-59,74166$ & \\
\hline \hline LR & 5,317723 & $-0,097017$ & & 0,862350 & $-1,831682$ & \\
\hline \hline N & 67 & 59 & - & 61 & 53 & - \\
\hline \hline
\end{tabular}


But test results for two creditor's financial variables regulated by the government, CAR and LR, shows insignificant results. It shows that creditor's problem of limited fund did not affect loan pricing decision made by creditor, which mean that risk factor play an important role in loan pricing decision.

\subsection{Test for Difference Loan Pricing}

Statistic test is taken to see whether the difference between each variable is significant or not. The test for equality of regression coefficients with z-test based on article written by Paternoster et al (1998).

The test results show (based on table 9.) for commercial bank and investment bank sub samples is not much different from standard model. But the ownership model have a higher adjusted $\mathrm{R}^{2}$ compare to standard model. While the significant level differences for term loan variable between investment bank and commercial bank become $10 \%$ higher into $5 \%$ level.

Table 9.

Regression Test for Difference Loan Pricing

\begin{tabular}{|c|c|c|c|c|c|c|}
\hline \multirow{2}{*}{ Variable } & \multicolumn{3}{|c|}{ Investment Bank vs Commercial Bank } & \multicolumn{3}{|c|}{ Domestic Creditor vs Foreign Creditor } \\
\hline & IB & $\mathrm{CB}$ & IB-CB & DC & FC & DC-FC \\
\hline TERM_LOAN & $-13,7644$ & $14,60245 * *$ & $-28,3669 * *$ & $-15,1661$ & 9,866875** & $-25,0330$ \\
\hline SIC_3 & $-23,6723$ & -26,0954** & 2,4231 & 32,36678 & $\begin{array}{c}- \\
25,4542^{* * *}\end{array}$ & $57,8210^{*}$ \\
\hline "SIC_8 & $-22,24$ & $-65,237 * * *$ & 42,9970 & - & $-39,5655^{*}$ & $39,5655^{*}$ \\
\hline Y95 & $-21,5958$ & $-47,8141^{*}$ & 26,2184 & 64,69988* & $-31,2816 * *$ & $95,9815 * *$ \\
\hline Y96 & $-33,8308$ & $-56,2813 * *$ & 22,4505 & $68,52563 * *$ & $\begin{array}{c}- \\
43,5769 * * *\end{array}$ & $112,1026^{* * *}$ \\
\hline Y97 & $-18,9415$ & $-46,5926^{*}$ & 27,6512 & $80,54525^{* * *}$ & $-38,2954 * *$ & $118,8406^{* * *}$ \\
\hline$\overline{\mathrm{N}}$ & 14145 & 4 & - & 82 & " 527 & - \\
\hline Adj. $\mathrm{R}^{2}$ & 0,309534 & 0,366197 & 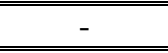 & 0,181274 & 0,349668 & 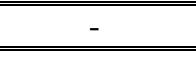 \\
\hline
\end{tabular}

Another test for ownership model for foreign creditor and domestic creditor sub samples, shows similar result like the previous one, where foreign creditor sub sample model is better than domestic creditor. The differences test also shows a similar result like the previous one, where regression coefficient differences is between industries variable and period variable.

In this research, robustness test also done by changing omitted variable from y92 into y94 in foreign creditor sub sample, to make period test comparable to domestic creditor sub sample that using y94 as omitted variable (since the data for y92 and y93 period are unavailable). The result shows the same consistency that foreign creditor tend to grant a lower loan pricing approaching economic crisis period.

For interaction sub sample, the test result is consistent with the previous analysis, where foreign commercial bank is better than domestic commercial bank, with adjusted $\mathrm{R}^{2}$ value of $34,86 \%$ and $14,81 \%$. The difference between loan pricing decision in domestic commercial bank and foreign commercial bank can only be seen in industries and period variables. Although ownership variable is added, the result from previous test remains the same.

Test result for domestic commercial bank and domestic invest bank sub samples for ownership model, shows a generally consistent conclusion compare to the 
previous test on foreign investment bank and domestic commercial bank sub samples with adjusted $\mathrm{R}^{2}$ value from mForeign models. While the equality test for regression coefficient shows a different pricing decision between two models, a consistent result compare to the previous test, where the differences is only between industries and period variable.

Table 10.

Regression Test for Difference Ownership Model

\begin{tabular}{|c|c|c|c|c|c|c|}
\hline \multirow[t]{2}{*}{ Variable } & \multicolumn{3}{|c|}{$\begin{array}{c}\text { Domestic Commercial Bank, Foreign } \\
\text { Investment Bank and Foreign Commercial } \\
\text { Bank }\end{array}$} & \multicolumn{3}{|c|}{ Differences } \\
\hline & DCB & FIB & FCB & DCB-FIB & FIB-FCB & DCB-FCB \\
\hline BOR_GOV & 2,662465 & $-11,0093$ & $-47,0992 * * *$ & 13,6717 & $36,0899 * *$ & 49,7616 \\
\hline SIC_2 & 17,63335 & $-63,6712^{* *}$ & $-5,59437$ & $81,3046 *$ & $\begin{array}{c}- \\
58,0769 * *\end{array}$ & 23,2277 \\
\hline SIC_3 & 26,14766 & $-50,2872 *$ & $-18,6109 * *$ & $76,4348 *$ & $-31,6762$ & 44,7586 \\
\hline SIC_4 & $-11,1999$ & $-79,393 * * *$ & $-16,9603$ & 68,1930 & $-62,4327 *$ & 5,7603 \\
\hline $\begin{array}{l}\text { SIC_5 } \\
\end{array}$ & $-21,3693$ & "-55,9037* & $-0,52722$ & 34,5344 & -55,3765* & $-20,8420$ \\
\hline SIC_6 & $-41,0957$ & $\begin{array}{c}- \\
94,5849 * * * \\
\end{array}$ & $-34,9625^{* * *}$ & 53,4892 & $\begin{array}{c}- \\
59,6224 * * \\
\end{array}$ & $-6,1332$ \\
\hline SIC_7 & $-25,6137$ & $-23,6851$ & $39,87279 * * *$ & $-1,9287$ & $\begin{array}{c}- \\
63,5578^{* *}\end{array}$ & $-65,4865 *$ \\
\hline SIC_8 & - & $-25,057$ & $-52,162 * * *$ & 25,0570 & 27,1050 & $52,1620^{* * * *}$ \\
\hline Y95 & 60,7503 & $-29,7933$ & $-40,4529 *$ & 90,5436* & 10,6597 & $101,2032 * *$ \\
\hline Y96 & 62,9358** & $-41,3015^{*}$ & -51,786** & $104,2373^{* * *}$ & 10,4846 & $114,7218^{* * *}$ \\
\hline Y97 & $84,29081 * * *$ & $-27,7437$ & $-50,2525 * *$ & $112,0345^{* * *}$ & 22,5088 & $134,5433^{* *}$ \\
\hline $\mathrm{N}$ & 72 & 135 & 392 & - & - & - \\
\hline Adj. $\mathrm{R}^{2}$ & 0,148154 & 0,34435 & 0,348699 & - & - & - \\
\hline F Value & $1,649914 *$ & $4,05988 * * *$ & $10,1016 * * *$ & - & - & - \\
\hline
\end{tabular}

For regression coefficient test (Table 10.), the result shows similar conclusion with the previous analysis, where the differences is only about debtor's industry risk determination. Although there is a differences in government ownership variable, but mForeign regression coefficient still have the same sign.

\section{CONCLUSION RECOMMENDATION}

AND

The result in this research shows the advantage owned by commercial bank to lower the asymmetric information level compare to investment bank is not proven, means there is no significant differences in loan pricing. In general, foreign creditor has a lower loan pricing compare to domestic creditor. Meanwhile, for domestic creditor, Private creditor has the highest loan pricing, followed by public creditor and the last is government creditor. The price comparison between government creditor and foreign creditor also did not show significant differences. The test also shows that there is no significant loan pricing differences between public and private debtor, except for government debtor, which means that government debtor have a low default risk 
since it is guaranteed by government. Other variable, which is special relationship condition impact on loan pricing, shows no significant regression coefficient, probably caused by inter group crossing between creditor and debtor in the same business groups. The test about funding cost shows that the higher funding cost from creditor will lead to higher loan pricing charged by creditor. Meanwhile, the creditor's financial variables regulated by government are found to be insignificant in all models.

Further research need to be taken to analyze whether there is a significant differences between loan pricing decision before and after economic crisis. This research also suspect that arranger structure can affect loan pricing, but further research is needed to analyze the arranger's structure in syndicated loans. 


\section{REFERENCES}

Barclay, M., and Smith, C. 1995. "The maturity structure of corporate debt” . Journal of Finance. 50, 609631.

Berlin, M., and Mester, L.J. 1992. "Debt Covenants and Renegotiation". Journal of Financial Intermediation. Vol.2, No.2, pp.95-133.

Bonin, J.P., and Leven, B. 1998. "Polish Bank Consolidation and Foreign Competition: Creating A Market Oriented Banking Sector”. Journal of Comparative Economics, Vol.23, No.1, pp.52-72.

Bonin, J.P., Hasan, I., and Wachtel, P. 2005. "Bank Performance, Efficiency and Ownership in Transition Countries". Journal of Banking and Finance, Vol.29, pp.31-53.

Booth, J. 1992. "Contract costs, bank loans, and the cross-monitoring hypothesis". Journal of Financial Economics, Vol.31, pp.25-41.

Booth, J.R. and Chua L. 1995. "Structure and Pricing of Large Bank Loans”. Federal Research Bank of San Francisco, Working Paper, pp.52-62.

Booth, J.R., and Booth, L.C. 2002. "Secured debt, monitoring, and corporate borrowing costs". Arizona State University, Working paper.

Boycko, M., Shleifer, A., and Vishny, R. 1996. "A Theory of Privateization”. Paish Lecture, Economic Journal, No. 106, pp.309-319.

Buch, C.M. 1997. "Opening Up the Foreign Banks-Why Central and Eastern Europe Can Benefit". Economics of Transition, Vol.5, No.2, pp.339-366.

Caballero, R., Hoshi, T., and Kashyap, A.K.. 2002..“Zombies”. University of Chicago, Working Paper.

Carey, M., Post, M., and Sharpe, S.A.. 1998. "Does Corporate Lending by Banks and Finance Companies Differ? Evidence on Specialization in Privatee Debt Contracting”. Journal of Finance, Vol.53, June, pp.845-878.

Carey, M. and Nini, G. 2003. "Is the Corporate Loan Market Globally Integrated? A Pricing Puzzle", Working Paper.

Chen, A.H., Mazumdar, S.C., Hung, M.W. 1996. "Regulations, Lender Identity and Bank Loan Pricing”. Pacific-Basin Finance Journal, Vol. 4, pp.1-1-14.

Chen, A.H., Mazumdar, S.C., Yan, Y. 2000. "Monitoring and bank loan pricing”. Pacific-Basin Finance Journal, Vol. 8, pp.1-24.

Coleman, A.D.F., Esho, N., and Sharpe, I.G. 2002. "Do Bank Characteristics Influence Loan Contract Term?”. Working Paper, February.

Datta, S., Datta, M.I., and Patel, A.. 1999. "Bank Monitoring and the Pricing of Corporate Public Debt". Journal of Financial Economics, Vol.51, pp.435-449.

Diamond, D. 1984. “Financial Intermediation and Delegated Monitoring”. Review of Economic Studies, Vol. 51, pp.393-414.

Drucker, P., and Puri, M. 2003. Typing Knots: Lending to Win Equity Underwriting Business. Unpublished working paper.

Fane, G., and McLeod, R.H. 2002. "Banking Collapse and Restructuring in Indonesia 1997-2001”. Cato Journal. Vol.22, No.2, Fall.

Fries, S., and Taci, A. 2002. "Banking Reform and Development in Transition Economies". EBRD, September.

Gande, A., Puri, M.,Saunders, A., and Walter, I. 1997. "Bank underwriting of debt securities: Modern evidence”. Review of Financial Studies, Vol. 10, 1175-1202.

Gottesman, A.A., and Roberts, G.S.. 2002. Maturity and Corporate Loan Pricing. Working Paper.

Grigorian, D., and Manole, V. 2002. "Determinants of Commercial Bank Performance in Transition: An Aplication of Data Envelopment Analysis”. World Bank Policy Research. Working Paper 2850, June. 
Gunarsih, T. 2003. Pengaruh Struktur Ownership dalam Good Corporate Governance dan Strategi Diversifikasi Terhadap Kinerja Perusahaan. Disertasi tidak diPublikasikan, Universitas Gadjah Mada.

Hallak, I. 2002. Why Borrower Pay Premium to Larger Lenders: Empirical Evidence from Sovereign Syndicated Loans, Center for Financial Studies, 2002/02, Working Paper.

Hao, L. 2003. Bank Effects and the Determinant of Loan Yield Spreads. Working Paper.

Harjoto, M., Mullineaux, D.J., and Yi, H.C. 2004. Loan Pricing at Investment Banks and Commercial Banks, Working Paper, Unpublished.

Hasan, I., and Marton, K.. 2003. "Development and Efficiency of the Banking Sector in a Transition Economy: Hungarian Experience” Journal of Banking and Finance, Vol.27, pp.2249-2271.

Heffernan, S.. 1996. Modern Banking in Theory and Practice, John Wiley and Sons.

Husnan, S. 2001. "Corporate Governance and Finance in East Asia: A Study of Indonesia, Republic of Korea, Malaysia, Philippines, and Thailand”. Vol.2, Country Studies, Asian Development Bank (ADB).

James, C. 1987 "Some Evidence of the Uniqueness of Bank Loans" Journal of Financial Economics, Vol.19, pp217-235.

John, K., Lynch, A.W., and Puri, M. 2003. "CreditrRatings, Collateral, and Loan Characteristics: Implications for Yield”. Journal of Business, 76, no.3.

Kikeri, S., Nellis, J., and Shirley, M. 1992. "Privateization: The Lessons of Experience”. The World Bank Paper, Washington D.C.

Laffont, J.J., and Tirole, J. 1993. A Theory of Incentives in Regulation and Procurement. Cambridge : MIT Press.

La Porta, R., De-Silanes, F.L., Shleifer, A., and Vishny, R.W. 1997. "Legal Determinants of External Finance" Journal of Finance, Vol.52, No.3, pp.1131-1150.

Levine, R. 1996. "Foreign Banks, Financial Development, and Economic Growth”. International Financial Markets: Harmonization Versus Competition. Washington D.C. :AEI Press.

Marciano, D. 2003. Loan pricing in United States, Europe and Asia. Working paper, unpublished.

McCauley, R.N., and Seth, R. 1992. "Foreign Bank Credit to US Corporation: the Implications of Offshore Loans”.Federal Reserve Bank of New York Quarterly Review, Vol.17, Spring.

Millon, M.H., and Thakor, A.V. 1985. "Moral Hazard and Information Sharing: A Model of Financial Information Gathering Agencies” Journal of Finance, (December), 1403-1422.

Mullineaux, D.J, and Roten, I.C. 2000. "Debt underwriting by commercial bank-affiliated firms and investment banks: More evidence”. Journal of Banking \& Finance, Vol. 26 (2002) 689-718.

Nikiel, E.M., and Opiela, T.P. 2002. "Customer Type and Bank Efficiency in Poland Implications for Emerging Market Banking”. Contemporary Economic Policy, Vol.20, No.3, pp.255-271.

Nini, G. 2004. The Value of Financial Intermediaries: Empirical Evidence From Syndicated Loan to Emerging Market Borrowers. Federal Reserve Bank, Working Paper.

Paternoster, R., Brame, R., Mazerolle, P., and Piquero, A. 1998. "Using The Correct Statistical Test for The Equality of Regression Coeficients”. Criminology, Vol.36, No.4, November, pp.859-866.

Petersen, M., and Rajan, R. 2002. "Does Distance Still Matter: the Information Revolution in Small Business Lending”. Journal of Finance, Vol.57, pp.2533-2570.

Roten, I., and Mullineaux, D.J. 2002. "Debt Underwriting by Commercial Bank-Affiliated Firms and Investment Banks: More Evidence”. Journal of Banking and Finance, Vol.26, pp.689-718.

Sappington, D., and Stiglitz, J. 1987. "Privateization, Information, and Incentives". Journal of Policy Analysis and Management, Vol.6, pp.567-582.

Shapiro, C., and Willig, R.D. 1990. "Economic Rationales for the Scope of Privateization", in E.N. Suleiman and J. Waterbury Eds.: The Political Economy of Public Sector Reform and Privateization, Western Press London, pp.55-87.

Shleifer, A., dan Vishnny, R.W. 1994. "Politicians and Firms”. Quarterly Journal of Economics, Vol.109, pp.995-1025. 
Shleifer, A., dan Vishnny, R.W. 1997. "A Survey of Corporate Governance”. Journal of Finance, Vol.52, No.2, June, pp.737-783.

Sinkey, J.F.Jr. 2002. Commercial bank financial management in the financial-services industry. Prentice Hall, Sixth edition.

Smith, C. 1980. "On The Theory of Financial Contracting: The Personal Loan Market”. Journal of Monetary Economics, Vol.6, pp.333-357.

Smith, D.C. 2003. “Loans to Japanese borrowers”. Journal of Japanese Int.Economies, Vol. 17, pp.283-304.

Strahan, P.E. 1999. "Borrower Risk and The Price and Nonprice Terms of Bank Loans". Working paper, Department of Finance, Boston College.

Stohs, M., and Mauer, D. 1996. "The Determinants of Corporate Debt Maturity Structure”. Journal of Business, Vol.69, pp.279-312.

Swandari, F. 2006. Pengaruh Tingkat Risiko dan Struktur Ownership Terhadap Kesulitan Keuangan Bank Umum di Indonesia: Kasus Krisis Keuangan Tahun 1997. PhD Thesis, Unpublished.

Swank, J. 1996 "Theories of The Banking Firm: A Review of Literature”. Bulletin of Economic Research, Vol. 48-3, pp.173-207. 